\section{The Effect of Providing Rehabilitation Technology Services through Vocational Rehabilitation in Persons with Amputation}

\author{
J Chad Duncan ${ }^{1 *}$, W Lee Childers ${ }^{2}$ and Joseph P Pete ${ }^{3}$ \\ ${ }^{1}$ Director, Department of Physical Medicine and Rehabilitation, Northwestern \\ University, Illinois, USA
}

${ }^{2}$ Senior Scientist, Department of Rehabilitation Medicine, Center for the Intrepid, Brooke Army Medical Center, Texas, USA

${ }^{3}$ Director, State of Louisiana Office of Addictive Disorders, Louisiana, USA

\begin{abstract}
Vocational Rehabilitation (VR) Services may benefit people with amputation. The objective of this research was to define the effect of receiving rehabilitation technology through Vocational Rehabilitation services on employment outcomes. The Rehabilitation Service Administration Case Service Report (RSA-911) database was filtered to include individuals that had amputation listed as the primary impairment and whose VR case was started and closed within 2007 and 2012. A forward model logistic regression analysis determined best predictors of employment while accounting for the effects of gender, race, presence of a comorbidity, and all 21 services (including assistive technology) provided by VR. $65.7 \%$ of the 10,107 cases identified achieved a positive employment outcome. VR Services had a positive effect on people with amputation attaining employment and within those services, providing rehabilitation technology significantly improved the odds of gaining employment. The continued provision of rehabilitation technology through VR services is warranted.
\end{abstract}

Keywords: Employment; Rehabilitation Technology; Vendor; Vocational Rehabilitation

*Corresponding author: J Chad Duncan, Director, Department of Physical Medicine and Rehabilitation, Northwestern University, Illinois, USA, Tel: + 1 3125038649; E-mail: jchad.duncan@northwestern.edu

Citation: Duncan JC, Childers WL, Pete J (2020) The Effect of Providing Rehabilitation Technology Services through Vocational Rehabilitation in Persons with Amputation. J Phys Med Rehabil Disabil 6: 060.

Received: June 24, 2020; Accepted: December 28, 2020; Published: December 31, 2020

Copyright: (c) 2020 Duncan JC, et al. This is an open-access article distributed under the terms of the Creative Commons Attribution License, which permits unrestricted use, distribution and reproduction in any medium, provided the original author and source are credited.

\section{Introduction}

Vocational Rehabilitation (VR) provides services to individuals with various disabilities who need assistance in obtaining gainful employment. These services are administered through state vocational rehabilitation programs and Veterans Affairs Vocational Rehabilitation and Employment programs. People with amputation can receive funding for Rehabilitation Technology/Assistive Technology (RT/ AT) [1] (e.g. prosthetic care) through VR services when the individual in obtaining specific employment and aids them in meeting the essential skills of that occupation.

VR services are provided in all fifty states and records for each individual case are combined into a national database (RSA-911). RSA-911 data contains each person's demographics, type of disability (e.g. amputation), all services provided through VR, the cost of those services, and employment outcomes. Therefore, the RSA-911 database provides a national sample with relevant outcome measures (e.g. employment) that could be used to demonstrate the effectiveness of rehabilitation technology/assistive technology to third party payers.

It is estimated there is 1.6 million persons living with limb loss/ absence in the United States and by 2050 there could be as many as 3.6 million [2]. Within the population of people living with amputation, there are limited data on employment. Its been reported employment/work is associated with many factors including self-worth, one's self-identity and community identity, and better health (mental and physical) outcomes of the individual [3-5]. When acquiring an amputation an individual is immediately at a disadvantage to maintain essential functions of the job (e.g. bimanual tasks, lifting, walking,) due to the limb absence. The Veterans Administration automatically assigns limb loss with a percentage of disability depending on the area of limb loss, (e.g. Code 5106: If both hands have been amputated, it is rated $100 \%$ disabled).

While self-identity and one's health has been shown to provide positive outcomes for individual, research has shown acquiring a disability, especially an amputation impacts the individual's chances for successful employment. Studies have documented negative outcomes on employment results ranging from $34-41 \%$ among individuals receiving lower limb amputations and return to work with utilization of $[6,7,8]$ rehabilitation technology (e.g. prosthesis, assistive technology). Similarly, to the previous mentioned research, [9] reported of 966 participants in their two (2) year repeated measure study on return to work and quality of life, $81.2 \%$ of the participants had one (1) or more return to work episodes, with $52 \%$ unsuccessfully maintaining work. While another study by Whyte and Carol [10], more than two decades ago, reported findings of persons who were employed prior to amputation and then return-to-work and employment had a retention at a rate of $43 \%$ leaving a $57 \%$ not successfully retaining employment. MacKenzie et al., [11] similary reported $42 \%$ of the 423 individuals who had been working prior to their lower limb trauma resulting in an amputation were unable to work 7-years post-amputation. MacKenzie, et al. concluded returning to work for individuals with sever 
Citation: Duncan JC, Childers WL, Pete J (2020) The Effect of Providing Rehabilitation Technology Services through Vocational Rehabilitation in Persons with Amputation. J Phys Med Rehabil Disabil 6: 060.

lower limb trauma is a challenge due to the multi-factors relating to the individual experience and work. While majority of studies cited have shown marginal success of employment for individuals with amputation within various entities, none directly reported from the Vocational Rehabilitation (RSA-911) data.

\section{Rehabilitation Technology}

Rehabilitation Act of 1973 (PL 93-112) define the term "rehabilitation technology" as the systematic application of technologies, engineering methodologies, or scientific principles to meet the needs of and address the barriers confronted by individuals with disabilities in areas which include education, rehabilitation, employment, transportation, independent living, and recreation. The term includes rehabilitation engineering, assistive technology devices, and assistive technology services. Thousands of technological devices can be classified as Assistive Technology (AT). These instruments include input devices, such as large print keyboards, and output devices, such as Braille embossers (e.g., printers).

The standard definition of an AT device is "any item, piece of equipment, or product system, whether acquired commercially offthe-shelf, modified, or customized, that is used to increase, maintain, or improve the functional capabilities of individuals with disabilities" (U.S. Congress, 1988). This broad definition covers any piece of technology that can help someone with a disability, and includes seven AT categories: Positioning, Mobility, Augmentative and Alternative Communication, Computer Access, Adaptive Toys and games, Adaptive Environments, and Instructional Aids [12]. Please note these categories are not exclusive, and often intertwine RT/AT devices and can range from a wheelchair to a customized prosthesis and/or universal design.

Well-documented evidence has been published in the research literature $[8,9,13,14]$ relevant to the effectiveness of RT/AT. Scherer, Vanbiervleit, Cushman, \& Scherer [14] found that when RT/AT matches the individual with disabilities needs and case processes occur collaborative between rehabilitation professionals there is a significant increase among individuals receiving positive outcomes and effective use of rehabilitation funds. While the Center on Effective Rehabilitation Technology (CERT) and Burton Blatt Institute (2012) reported findings from 2010 RSA-911 data showing that $32 \%$ of individuals with disabilities receiving rehabilitation and assistive technology (RT/AT) within VR (e.g., state-federal vocational rehabilitation services) exited without a positive employment outcome.

While several studies have noted the varying successes of matching technology with persons with disabilities as a whole grouping, they have not shown the impact of RT/AT success specifically related to persons with amputation. Amputation is of interest due to the immediate impact on an individual's ability to perform functional activities of work. Within the VR system it is critical to understand the impact of the amputation on the person's ability to perform the functional task of job, current or a future job or schooling. For individuals who have entered the VR system with amputation one might have to regain some form of independence and the ability to perform functional tasks utilizing some type of RT/AT (e.g. wheelchair, prosthetics, graspers). Currently, literature has not evaluated the impact of RT/AT has on individuals with amputation within the VR system.
Therefore, the purpose of this work was to define the effect of receiving rehabilitation technology through Vocational Rehabilitation services on employment outcomes in people with amputation.

\section{Methods}

\section{Participants}

Data for the current study were extracted from the U.S. Department of Education's Rehabilitation Service Administration Case Service Report (RSA-911) database, which is a large administrative dataset that includes detailed information regarding demographics, disability, types of services, and employment outcomes for people with disabilities receiving state VR services in the United States. Any individual having amputation listed as the primary impairment and whose vocational rehabilitation case was started and closed (with or without an employment outcome) between years 2007 and 2012 were included for subsequent analysis.

\section{Outcome variables}

Outcome variables were competitive employment, hourly wage at closure, and primary support at closure. An individual was said to have competitive employment when they work in an integrated setting, self-employed, or in a state-managed Business Enterprise Program and the person is compensated at above minimum wage. Hourly wage at closure was calculated as the amount of reported weekly earnings divided by the hours worked per week. Primary support at closure was defined as either the individual's primary source of income came from personal income or from public support (Supplemental Security Income, Temporary Assistance for Needy Families, etc.).

A forward model logistic regression analysis determined best predictors of competitive employment. Those potential predictors include gender, race, presence of a comorbidity, all the different services provided by VR, and receipt of a prosthesis. This was necessary so that the model could correct for the potential confounding effect of another service. Significance was set at $\mathrm{p}<0.05$.

\section{Independent variables}

Specific independent variables were gender, race, presence of a secondary disability, VR guidance and counseling, college or university training, occupational vocational training, on-the-job training, basic academic remedial literacy or literacy training, job readiness training, disability related augmentative skills training, miscellaneous training, job search assistance, job placement assistance, on-the-job support, transportation services, maintenance services, and the receipt of rehabilitation technology.

\section{Results}

A total of 10,107 individuals with amputation listed as the primary disability, utilized VR services, and had an employment outcome were identified in the RSA-911 database between years 2007 and 2012. The individuals were predominantly Male and white (nonhispanic) (Table 1). 6641 out of 10,107 (65.7\%) achieved a positive employment outcome. The most common VR service provided was vocational rehabilitation counseling (7895) and the least common was literacy training (57) (Table 2). 
Citation: Duncan JC, Childers WL, Pete J (2020) The Effect of Providing Rehabilitation Technology Services through Vocational Rehabilitation in Persons with Amputation. J Phys Med Rehabil Disabil 6: 060.

\begin{tabular}{|c|c|c|c|c|c|c|}
\hline Classification & White (non-Hispanic) & Black (non-Hispanic) & Native American (non-Hispanic) & Asian/ Pacific Islander (non-Hispanic) & Hispanic & Total \\
\hline Male & 5036 & 1511 & 73 & 135 & 904 & 7659 \\
\hline Female & 1524 & 618 & 27 & 38 & 241 & 2448 \\
\hline
\end{tabular}

Table 1: Breakdown of the dataset with regards to the number of males and females within each classified race.

\begin{tabular}{|c|c|c|c|}
\hline Receipt of a service or presence of a comorbidity & Did not achieve employment & Achieved employment & Total \\
\hline Assessment & 2336 & 4418 & 6754 \\
\hline Diagnosis and treatment of impairments & 1706 & 3974 & 5680 \\
\hline Vocational rehab counseling & 2617 & 5278 & 7895 \\
\hline Graduate College or University training & 476 & 549 & 1025 \\
\hline On-the-job training & 22 & 124 & 146 \\
\hline Literacy training & 24 & 33 & 57 \\
\hline Job readiness training & 350 & 504 & 854 \\
\hline Disability related skills training & 49 & 112 & 161 \\
\hline Miscellaneous training & 243 & 362 & 605 \\
\hline Job search assistance & 705 & 1278 & 1983 \\
\hline Job placement assistance & 757 & 1640 & 2397 \\
\hline On-the-job support & 165 & 662 & 827 \\
\hline Transportation & 916 & 1211 & 2127 \\
\hline Maintenance & 438 & 1001 & 1439 \\
\hline Rehabilitation Technology & 589 & 2090 & 2679 \\
\hline Presence of a comorbidity & 1745 & 2099 & 3844 \\
\hline
\end{tabular}

Table 2: Breakdown of the dataset by number that received a VR service, and number that had an additional comorbidity with whether or not an employment outcome was achieved.

There was a significant positive effect of on-the-job training, onthe-job support, rehabilitation technology, diagnosis and treatment of impairments, maintenance, and job placement assistance (Table 3) on people with amputation gaining employment through VR services after controlling for all other demographic and VR service factors. There was no significant effect of gender or race in people with amputation attaining employment through VR services (Table 3 ). The presence of a comorbidity in addition to the amputation had a significant negative effect with the lowest odds ratio ( 0.42 or someone with an amputation and a comorbidity is 2.36 times less likely to gain employment) (Table 3).

\section{Discussion}

Bolton, Bellini, and Brookings [15] reported that rehabilitation outcome research should focus on answering the question, "Which approach work best for whom, how, and under what conditions?" The researchers contended that answering this question would provide counselors with information regarding the personal factors and service provision patterns that have a high probability of predicting successful VR outcomes for specified consumer subgroups. For this reason, predictors of employment outcome research have continued to be utilized over the past several decades. In general, this line of research has become increasingly more utilized by state-federal VR programs. With the increasing pressures that have been exerted on the field of VR by evidence-based practice, predictors of employment outcome research have provided state-federal VR programs with a mechanism to translate research into practice and continue to demonstrate that VR services are effective.
The most important finding of this study was that VR services resulted in people with amputation finding competitive employment more often than previous studies. In addition, VR services that include on-the-job training, on-the-job support, and rehabilitation technology all increase the odds of someone with an amputation gaining employment. These findings were significant after controlling for all other potential confounding variables such as gender, race, and other services provided through VR. It is imperative for statefederal VR programs to continue to demonstrate that VR services are effective and that state-federal VR programs are predicated on the discipline utilizing evidence-based interventions and best practices that integrate the best research evidence with clinical expertise and client perspectives to yield successful VR outcomes [16,17].

The used of archival data (e.g., RSA 911) and conducting ex post facto study design has provided rehabilitation researchers utility to established a well-documented record of effectiveness of state federal vocational rehabilitation (VR) services in the research literature. Additionally, results from this study provide research evidence that rehabilitation technology is particularly effective among consumers with amputations who receive VR services. Data can be utilized to provide information of knowledge of type of services that facilitate and/or predict successful VR case closers. Provide information to VR administrators and Rehabilitation Counselors to enhance service provision utilizing best practice based on research and continuous quality improvement of VR as a viable service options for persons with disabilities to return to work and improve quality of life [18-25]. 
Citation: Duncan JC, Childers WL, Pete J (2020) The Effect of Providing Rehabilitation Technology Services through Vocational Rehabilitation in Persons with Amputation. J Phys Med Rehabil Disabil 6: 060.

\begin{tabular}{|c|c|c|c|c|c|}
\hline \multirow{2}{*}{ Receipt of a service or presence of a comorbidity } & \multirow{2}{*}{ Overall positive of negative effect } & \multirow{2}{*}{ P-value } & \multirow{2}{*}{ Odds Ratio } & \multicolumn{2}{|c|}{$95 \%$ Confidence Interval } \\
\hline & & & & Lower Limit & Upper Limit \\
\hline On-the-job training & Positive & $<0.001$ & 3.2 & 1.98 & 5.15 \\
\hline On-the-job support & Positive & $<0.001$ & 2.28 & 1.89 & 2.74 \\
\hline Rehabilitation Technology & Positive & $<0.001$ & 2.2 & 1.96 & 2.46 \\
\hline Diagnosis and treatment of impairments & Positive & $<0.001$ & 1.58 & 1.44 & 1.73 \\
\hline Maintenance & Positive & $<0.001$ & 1.49 & 1.31 & 1.7 \\
\hline Job placement assistance & Positive & $<0.001$ & 1.49 & 1.32 & 1.68 \\
\hline Being Asian & Positive & 0.201 & 1.42 & 0.83 & 2.41 \\
\hline Being Native Hawaiian / Pacific Islander & Positive & 0.302 & 1.41 & 0.73 & 2.73 \\
\hline Being White & Positive & 0.144 & 1.41 & 0.89 & 2.25 \\
\hline Vocational rehab counseling & Positive & 0.003 & 1.18 & 1.06 & 1.31 \\
\hline Disability related skills training & Positive & 0.868 & 1.03 & 0.72 & 1.48 \\
\hline Being Male & Positive & 0.692 & 1.02 & 0.92 & 1.13 \\
\hline Assessment & Negative & 0.304 & 0.95 & 0.87 & 1.05 \\
\hline Job search assistance & Negative & 0.417 & 0.95 & 0.84 & 1.08 \\
\hline Being Hispanic & Negative & 0.301 & 0.93 & 0.81 & 1.07 \\
\hline Being Black / African American & Negative & 0.582 & 0.88 & 0.55 & 1.4 \\
\hline Literacy training & Negative & 0.493 & 0.82 & 0.46 & 1.46 \\
\hline Miscellaneous training & Negative & 0.026 & 0.81 & 0.68 & 0.98 \\
\hline Being Native American & Negative & 0.359 & 0.8 & 0.5 & 1.28 \\
\hline Job readiness training & Negative & $<0.001$ & 0.75 & 0.64 & 0.88 \\
\hline Transportation & Negative & $<0.001$ & 0.67 & 0.6 & 0.76 \\
\hline Graduate College or University training & Negative & $<0.001$ & 0.66 & 0.58 & 0.76 \\
\hline Presence of a comorbidity & Negative & $<0.001$ & 0.46 & 0.42 & 0.51 \\
\hline
\end{tabular}

Table 3: Predictors of employment based on Vocational rehabilitation service provided, gender, race, or the presence of a comorbidity.

\section{Limitations}

This study used archival data and employed an ex post facto design; therefore, causality was not able to be determined. The data originates with rehabilitation counselors entering case information at different points during the VR process and may affect the reliability of the data. The RSA-911 dataset provides very limited information and other potentially significant demographic covariates (e.g., type of rehabilitation technology received, level of amputation, etc.) that present substantial challenges in identifying what rehabilitation technology are most effective because this particular data are not available for analysis. Therefore, creating a void in the research literature as to what rehabilitation technology is most effective and predict successful employment outcomes.

\section{Ambiguous coding directives for services provided}

The RSA-911 data that were used in this study were gathered from information input by VR counselors at various stages in the VR service delivery process, so it is possible that counselors made accidental data input errors. In addition, information on disability type was entered prior to an eligibility decision, and the wage and occupation information were entered when the case was closed. Therefore, data could be incorrect if the counselors relied only on memory and did not consult the case records to verify that services that were actually delivered. Although the RSA has developed 18 cross-checks to reduce the potential for these types of errors, an unknown number of errors may possibly still exist. Fortunately, these errors are assumed to be random and therefore should not result in systematic bias in the data (RSA, 2004).

\section{Generalizability}

The study utilized an archival dataset as the source of data and included a national database of consumers with amputation as primary disability who received rehabilitation technology (i.e., prosthesis) VR services. Therefore, the results can be generalized to this population and considered acceptable because the study seeks to identify VR services that the United States state-federal VR agencies record and utilize to examine and identify predictor variables that lead to successful employment outcomes.

\section{Nonspecificity in coding severity of level/severity of amputation}

Because the RSA (2009) does not indicate the level of severity of an individual's disability for consumers with amputation, the coding scheme does not allow for the identification of level of functioning. For this reason, the results of the study were limited in that they do not identify more distinct categories of impairment and/or the presence of positive or negative symptoms that could present substantial challenges in the VR process. For example, cognitive deficits may include impairments in attention, working memory, learning, general knowledge, ideational skills, or problem solving skills. Negative symptoms can include loss of interest and motivation, an inability to 
Citation: Duncan JC, Childers WL, Pete J (2020) The Effect of Providing Rehabilitation Technology Services through Vocational Rehabilitation in Persons with Amputation. J Phys Med Rehabil Disabil 6: 060.

initiate action, apathy, and social withdrawal. As a result, a person can experience limitations in daily functioning that include, but are not limited to, problems coping with stress, concentration, interpersonal skills, or social skills, all of which can be major barriers to a consumer who is seeking or wanting to maintain employment.

\section{Problems of multicollinearity}

Because of the exceptionally large sample size $(n=10,107)$, problems of multicollinearity were anticipated. Various checks for indicators of multicollinearity were conducted, but no indicators were found. Therefore, this study is not considered to have a problem with multicollinearity.

\section{Implication for research/practice}

Additional research further investigating the effects VR services has on the employment outcomes of consumers with amputation utilizing state federal VR for rehabilitation technology (e.g., prosthesis) is warranted. For this reason, VR efforts to include variables in the case reporting system that identify what types of rehabilitation technology are being provided to consumers is also warranted. As a final point, this information can be useful for VR counselors to gain insight to help formulate best practices to improve service delivery among state-federal VR consumers who primary disability is amputation and employment goal include receipt of rehabilitation technology (i.e., prosthesis).

\section{Conclusion}

This study was effective in that its findings, as they applied to consumers with amputations who are recipients of rehabilitation technology, were consistent with previous employer and rehabilitation research on predictor variables. By learning about specific VR services and demographic variables that can result in an increased likelihood of successful employment outcomes, VR counselors will improve their practice, will become more effective, and will increase state-federal VR accountability to their consumers and stakeholders. One of the most important implications for administration and data collection for consumers with amputation is perhaps to improve upon coding practices. More specific coding as it relates to the level of functioning and type of rehabilitation technology received could possibly yield more salient information to improve VR services and intervention plans to better achieve successful employment outcomes. By doing so, specific interventions can be established to serve a range of consumers and help eliminate the ambiguities that result as it relates to different levels of functioning and type of RT received for VR consumers with amputation and receipt of RT. These improvements are all very important in this day and age with the advent of evidencebased practice that has impacted rehabilitation counseling as well as rehabilitation research, and all other service provision entities.

\section{Acknowledgement}

The authors gratefully acknowledge Drs. John Kramer, Myra Reynoso for their help in the preparation of this article, Dr. Ngai Kwan for his help with the statistical analysis, and Dr. Corey Moore with the Langston Rehabilitation Research Training Center for supporting our efforts and providing access to the RSA 911 database.

The financial support for this research was provided by the National Institute on Disability, Independent Living, and Rehabilitation
Research (NIDILRR grant number 90RT5024-01-00) to the Langston University Rehabilitation Research and Training Center (LU-RRTC) on Research and Capacity Building for Minority Entities through a collaborative subcontract with the University of Massachusetts Boston Institute for Community Inclusion (ICI). NIDILRR is a Center within the Administration for Community Living (ACL), Department of Health and Human Services (HHS). The contents of this report do not necessarily represent the policy of NIDILRR, ACL, HHS, and you should not assume endorsement by the Federal Government.

\section{References}

1. AFB (2005) Assistive Technology Act 2004. American Foundation for the Blind, Virginia, USA.

2. Ziegler-Graham K, MacKenzie EJ, Ephraim PL, Travison TG, Brookmeyer R (2008) Estimating the prevalence of limb loss in the United States: 2005 to 2050. Archives Physical Medicine Rehabilitation 89: 422-429.

3. Frank A (2016) Vocational rehabilitation: Supporting ill or disabled individuals in (to) work: A UK perspective. Healthcare 4: 46.

4. Black DC (2008) Working for a healthier tomorrow: work and health in Britain. The Stationary Office, London, UK.

5. Waddell G, Burton AK (2006) Is work good for your health and well-being? The Stationary Office, London, UK.

6. Fisher K, Hanspel RS, Marks L (2003) Return to work after lower limb amputation. Int J Rehabil Res 26: 51-55.

7. Schoppen TD, Boonstra A, Groothoff JW, de Vries J, Goeken LN, et al. (2001) Employment status, job characteristics, and work-related health experience of people with a lower limb amputation in The Netherlands. Arch Phys Med Rehabil 82: 239-245.

8. Dasgupta AK, McCluskie PJA, Patel VS, Robins L (1997) The performance of the ICEROSS prostheses amongst transtibial amputees with a special reference to the workplace--a preliminary study. Icelandic Roll on Silicone Socket. Occup Med 47: 228-236.

9. Hou WH, Liang HW, Sheu CF, Hsieh CL, Chuang HY (2013) Return to work and quality of life in workers with traumatic limb injuries: a 2-year repeated-measurements study. Archives Physical Medicine Rehabilitation 94: 703-710.

10. Whyte AS, Coral LJ (2002) A preliminary examination of the relationship between employment, pain and disability in an amputee population. Disabil Rehabil 24: 462-470.

11. MacKenzie EJ, Bosse MJ, Kellam JF, Pollak AN, Webb LX, et al. (2006) Early predictors of long-term work disability after major limb trauma. The Journal of Trauma: Injury, Infection, and Critical Care 61: 688-694.

12. Bryant DP, Bryant BR (2003) Assistive Technology for people with disabilities. Allyn \& Bacon, Boston, USA.

13. Schoppen T, Boonstra A, Groothoff JW, De Vries J, Göeken LN, et al. (2002) Job satisfaction and health experience of people with a lower-limb amputation in comparison with healthy colleagues. Archives of Physical Medicine and Rehabilitation 83: 628-634.

14. Scherer MJ, Sax C, Vanbiervleit A, Cushman LA, Scherer JV (2005) Predictors of assistive technology use: The importance of personal and psychosocial factors. Disability and Rehabilitation 27: 1321-1331.

15. Bolton BF, Bellini JL, Brookings JB (2000) redicting Client Employment Outcomes from Personal History, Functional Limitations, and Rehabilitation Services. Rehabilitation Counseling Bulletin 44: 10-21.

16. Chan F, Rosenthal D, Pruett S (2008) Evidence-based practice in the provision of rehabilitation services. Journal of Rehabilitation 74: 3-5. 
Citation: Duncan JC, Childers WL, Pete J (2020) The Effect of Providing Rehabilitation Technology Services through Vocational Rehabilitation in Persons with Amputation. J Phys Med Rehabil Disabil 6: 060.

17. Dutta A, Gervey R, Chan F, Chou CC, Ditchman N (2008) Vocational rehabilitation services and employment outcomes for people with disabilities: A United States study. Journal of Occupational Rehabilitation 18: 326-334.

18. Carlson D, Ehrlich N (2005) Assistive technology and information technology use and need by persons with disabilities in the United States, 2001. National Institute on Disability Rehabilitation Research, Washington, D.C., USA.

19. Gerhards F, Florin I, Knapp T (1984) The impact of medical, reeducational, and psychological variables on rehabilitation outcome in amputees. International Journal Rehabilitation Research 7: 379-388.

20. Hager R (1999) State Vocational Rehabilitation Agencies: Using Assistive Technology to Maximize Employment. Clearinghouse Review 33: 413 432.

21. Noll A, Owens L, Smith RO, Schwanke T (2006) Survey of state vocational rehabilitation counselor roles and competencies in assistive technology. Work 27: 413-419.
22. Schwanke TD, Smith RO (2005) Assistive technology outcomes in work settings. Work 24: 195-204.

23. Sirzai H, Koseoglu BF, Kilinc G, Ozel S (2016) Return to work after amputation. Turkish Journal of Physical Medicine and Rehabilitation 62.

24. Solomon D (2016) Save the Social Security Disability Trust Fund! and Reduce SSI Exposure to the General Fund. Journal of the National Association of Administrative Law Judiciary 36: 142-242.

25. Schoppen T, Boonstra A, Groothoff JW, van Sonderen E, Goeken LN, et al. (2001) Factors related to successful job reintegration of people with a lower limb amputation. Archives of Physical Medicine and Rehabilitation 82: 1425-1431. 


\section{Hif}

Advances In Industrial Biotechnology | ISSN: 2639-5665

Advances In Microbiology Research | ISSN: 2689-694X

Archives Of Surgery And Surgical Education | ISSN: 2689-3126

Archives Of Urology

Archives Of Zoological Studies | ISSN: 2640-7779

Current Trends Medical And Biological Engineering

International Journal Of Case Reports And Therapeutic Studies | ISSN: 2689-310X

Journal Of Addiction \& Addictive Disorders | ISSN: 2578-7276

Journal Of Agronomy \& Agricultural Science | ISSN: 2689-8292

Journal Of AIDS Clinical Research \& STDs | ISSN: 2572-7370

Journal Of Alcoholism Drug Abuse \& Substance Dependence | ISSN: 2572-9594

Journal Of Allergy Disorders \& Therapy | ISSN: 2470-749X

Journal Of Alternative Complementary \& Integrative Medicine | ISSN: 2470-7562

Journal Of Alzheimers \& Neurodegenerative Diseases | ISSN: 2572-9608

Journal Of Anesthesia \& Clinical Care | ISSN: 2378-8879

Journal Of Angiology \& Vascular Surgery | ISSN: 2572-7397

Journal Of Animal Research \& Veterinary Science | ISSN: 2639-375

Journal Of Aquaculture \& Fisheries | ISSN: 2576-5523

Journal Of Atmospheric \& Earth Sciences | ISSN: 2689-8780

Journal Of Biotech Research \& Biochemistry

Journal Of Brain \& Neuroscience Research

Journal Of Cancer Biology \& Treatment | ISSN: 2470-7546

Journal Of Cardiology Study \& Research | ISSN: 2640-768X

Journal Of Cell Biology \& Cell Metabolism | ISSN: 2381-1943

Journal Of Clinical Dermatology \& Therapy | ISSN: 2378-8771

Journal Of Clinical Immunology \& Immunotherapy | ISSN: 2378-8844

Journal Of Clinical Studies \& Medical Case Reports | ISSN: 2378-880

Journal Of Community Medicine \& Public Health Care | ISSN: 2381-1978

Journal Of Cytology \& Tissue Biology | ISSN: 2378-9107

Journal Of Dairy Research \& Technology | ISSN: 2688-9315

Journal Of Dentistry Oral Health \& Cosmesis | ISSN: 2473-6783

Journal Of Diabetes \& Metabolic Disorders | ISSN: 2381-201X

Journal Of Emergency Medicine Trauma \& Surgical Care | ISSN: 2378-8798

Journal Of Environmental Science Current Research | ISSN: 2643-5020

Journal Of Food Science \& Nutrition | ISSN: 2470-1076

Journal Of Forensic Legal \& Investigative Sciences | ISSN: 2473-733X

Journal Of Gastroenterology \& Hepatology Research | ISSN: 2574-2566
Journal Of Genetics \& Genomic Sciences | ISSN: 2574-2485

Journal Of Gerontology \& Geriatric Medicine | ISSN: 2381-8662

Journal Of Hematology Blood Transfusion \& Disorders | ISSN: 2572-2999

Journal Of Hospice \& Palliative Medical Care

Journal Of Human Endocrinology | ISSN: 2572-9640

Journal Of Infectious \& Non Infectious Diseases | ISSN: 2381-8654

Journal Of Internal Medicine \& Primary Healthcare | ISSN: 2574-2493

Journal Of Light \& Laser Current Trends

Journal Of Medicine Study \& Research | ISSN: 2639-5657

Journal Of Modern Chemical Sciences

Journal Of Nanotechnology Nanomedicine \& Nanobiotechnology | ISSN: 2381-2044

Journal Of Neonatology \& Clinical Pediatrics | ISSN: 2378-878X

Journal Of Nephrology \& Renal Therapy | ISSN: 2473-7313

Journal Of Non Invasive Vascular Investigation | ISSN: 2572-7400

Journal Of Nuclear Medicine Radiology \& Radiation Therapy | ISSN: 2572-7419

Journal Of Obesity \& Weight Loss | ISSN: 2473-7372

Journal Of Ophthalmology \& Clinical Research | ISSN: 2378-8887

Journal Of Orthopedic Research \& Physiotherapy | ISSN: 2381-2052

Journal Of Otolaryngology Head \& Neck Surgery | ISSN: 2573-010X

Journal Of Pathology Clinical \& Medical Research

Journal Of Pharmacology Pharmaceutics \& Pharmacovigilance | ISSN: 2639-5649

Journal Of Physical Medicine Rehabilitation \& Disabilities | ISSN: 2381-8670

Journal Of Plant Science Current Research | ISSN: 2639-3743

Journal Of Practical \& Professional Nursing | ISSN: 2639-568

Journal Of Protein Research \& Bioinformatics

Journal Of Psychiatry Depression \& Anxiety | ISSN: 2573-0150

Journal Of Pulmonary Medicine \& Respiratory Research | ISSN: 2573-0177

Journal Of Reproductive Medicine Gynaecology \& Obstetrics | ISSN: 2574-2574

Journal Of Stem Cells Research Development \& Therapy | ISSN: 2381-2060

Journal Of Surgery Current Trends \& Innovations | ISSN: 2578-7284

Journal Of Toxicology Current Research | ISSN: 2639-3735

Journal Of Translational Science And Research

Journal Of Vaccines Research \& Vaccination | ISSN: 2573-0193

Journal Of Virology \& Antivirals

Sports Medicine And Injury Care Journal | ISSN: 2689-8829

Trends In Anatomy \& Physiology | ISSN: 2640-7752

Submit Your Manuscript: https://www.heraldopenaccess.us/submit-manuscript 